\title{
International Convention against the Recruitment, Use, Financing and Training of Mercenaries ${ }^{1}$
}

\section{Adopted and opened for signature and ratification by General Assembly resoluti- on $44 / 34$ of 4 December 1989}

\section{Entry into force: 20 October 2001, in accordance with article 19}

The States Parties to the present Convention,

Reaffirming the purposes and principles enshrined in the Charter of the United Nations and in the Declaration on Principles of International Law concerning Friendly Relations and Cooperation among States in accordance with the Charter of the United Nations,

Being aware of the recruitment, use, financing and training of mercenaries for activities which violate principles of international law, such as those of sovereign equality, political independence, territorial integrity of States and self-determination of peoples,

Affirming that the recruitment, use, financing and training of mercenaries should be considered as offences of grave concern to all States and that any person committing any of these offences should be either prosecuted or extradited,

Convinced of the necessity to develop and enhance international co-operation among States for the prevention, prosecution and punishment of such offences,

Expressing concern at new unlawful international activities linking drug traffickers and mercenaries in the perpetration of violent actions which undermine the constitutional order of States,

Also convinced that the adoption of a convention against the recruitment, use, financing and training of mercenaries would contribute to the eradication of these nefarious activities and thereby to the observance of the purposes and principles enshrined in the Charter,

Cognizant that matters not regulated by such a convention continue to be governed by the rules and principles of international law,

Have agreed as follows:

\section{Article 1}

For the purposes of the present Convention,

1. A mercenary is any person who:

( a ) Is specially recruited locally or abroad in order to fight in an armed conflict;

(b) Is motivated to take part in the hostilities essentially by the desire for private gain and, in fact, is promised, by or on behalf of a party to the conflict, material compensation substantially

1 http://www2.ohchr.org/english/law/mercenaries.htm in excess of that promised or paid to combatants of similar rank and functions in the armed forces of that party;

(c) Is neither a national of a party to the conflict nor a resident of territory controlled by a party to the conflict;

( d ) Is not a member of the armed forces of a party to the conflict; and

( e ) Has not been sent by a State which is not a party to the conflict on official duty as a member of its armed forces.

2. A mercenary is also any person who, in any other situation:

( a ) Is specially recruited locally or abroad for the purpose of participating in a concerted act of violence aimed at:

(i) Overthrowing a Government or otherwise undermining the constitutional order of a State; or

(ii) Undermining the territorial integrity of a State;

( b ) Is motivated to take part therein essentially by the desire for significant private gain and is prompted by the promise or payment of material compensation;

( c ) Is neither a national nor a resident of the State against which such an act is directed;

( d ) Has not been sent by a State on official duty; and

(e ) Is not a member of the armed forces of the State on whose territory the act is undertaken.

\section{Article 2}

Any person who recruits, uses, finances or trains mercenaries, as defined in article 1 of the present Convention, commits an offence for the purposes of the Convention.

Article 3

1. A mercenary, as defined in article 1 of the present Convention, who participates directly in hostilities or in a concerted act of violence, as the case may be, commits an offence for the purposes of the Convention.

2. Nothing in this article limits the scope of application of article 4 of the present Convention.

\section{Article 4}

An offence is committed by any person who:

( a ) Attempts to commit one of the offences set forth in the present Convention; 
( b ) Is the accomplice of a person who commits or attempts to commit any of the offences set forth in the present Convention.

\section{Article 5}

1. States Parties shall not recruit, use, finance or train mercenaries and shall prohibit such activities in accordance with the provisions of the present Convention.

2. States Parties shall not recruit, use, finance or train mercenaries for the purpose of opposing the legitimate exercise of the inalienable right of peoples to self-determination, as recognized by international law, and shall take, in conformity with international law, the appropriate measures to prevent the recruitment, use, financing or training of mercenaries for that purpose.

3. They shall make the offences set forth in the present Convention punishable by appropriate penalties which take into account the grave nature of those offences.

\section{Article 6}

States Parties shall co-operate in the prevention of the offences set forth in the present Convention, particularly by:

( a ) Taking all practicable measures to prevent preparations in their respective territories for the commission of those offences within or outside their territories, including the prohibition of illegal activities of persons, groups and organizations that encourage, instigate, organize or engage in the perpetration of such offences;

( $b$ ) Co-ordinating the taking of administrative and other measures as appropriate to prevent the commission of those offences.

\section{Article 7}

States Parties shall co-operate in taking the necessary measures for the implementation of the present Convention.

\section{Article 8}

Any State Party having reason to believe that one of the offences set forth in the present Convention has been, is being or will be committed shall, in accordance with its national law, communicate the relevant information, as soon as it comes to its knowledge, directly or through the Secretary-General of the United Nations, to the States Parties affected.

\section{Article 9}

1. Each State Party shall take such measures as may be necessary to establish its jurisdiction over any of the offences set forth in the present Convention which are committed:

( a ) In its territory or on board a ship or aircraft registered in that State;

(b) By any of its nationals or, if that State considers it appropriate, by those stateless persons who have their habitual residence in that territory.

2. Each State Party shall likewise take such measures as may be necessary to establish its jurisdiction over the offences set forth in articles 2, 3 and 4 of the present Convention in cases where the alleged offender is present in its territory and it does note extradite him to any of the States mentioned in paragraph 1 of this article.

3. The present Convention does not exclude any criminal jurisdiction exercised in accordance with national law.

\section{Article 10}

1. Upon being satisfied that the circumstances so warrant, any State Party in whose territory the alleged offender is present shall, in accordance with its laws, take him into custody or take such other measures to ensure his presence for such time as is necessary to enable any criminal or extradition proceedings to be instituted. The State Party shall immediately make a preliminary inquiry into the facts.

2. When a State Party, pursuant to this article, has taken a person into custody or has taken such other measures referred to in paragraph 1 of this article, it shall notify without delay either directly or through the Secretary-General of the United Nations:

(a ) The State Party where the offence was committed;

(b) The State Party against which the offence has been directed or attempted;

( c ) The State Party of which the natural or juridical person against whom the offence has been directed or attempted is a national;

(d) The State Party of which the alleged offender is a national or, if he is a stateless person, in whose territory he has his habitual residence;

( e ) Any other interested State Party which it considers it appropriate to notify.

3. Any person regarding whom the measures referred to in paragraph 1 of this article are being taken shall be entitled:

( a ) To communicate without delay with the nearest appropriate representative of the State of which he is a national or which is otherwise entitled to protect his rights or, if he is a stateless person, the State in whose territory he has his habitual residence;

( b ) To be visited by a representative of that State.

4. The provisions of paragraph 3 of this article shall be without prejudice to the right of any State Party having a claim to jurisdiction in accordance with article 9, paragraph 1 ( b ), to invite the International Committee of the Red Cross to communicate with and visit the alleged offender.

5. The State which makes the preliminary inquiry contemplated in paragraph 1 of this article shall promptly report its findings to the States referred to in paragraph 2 of this article and indicate whether it intends to exercise jurisdiction.

\section{Article 11}

Any person regarding whom proceedings are being carried out in connection with any of the offences set forth in the present Convention shall be guaranteed at all stages of the proceedings fair treatment and all the rights and guarantees provided for in the law of the State in question. Applicable norms of international law should be taken into account. 


\section{Article 12}

The State Party in whose territory the alleged offender is found shall, if it does not extradite him, be obliged, without exception whatsoever and whether or not the offence was committed in its territory, to submit the case to its competent authorities for the purpose of prosecution, through proceedings in accordance with the laws of that State. Those authorities shall take their decision in the same manner as in the case of any other offence of a grave nature under the law of that State.

\section{Article 13}

1. States Parties shall afford one another the greatest measure of assistance in connection with criminal proceedings brought in respect of the offences set forth in the present Convention, including the supply of all evidence at their disposal necessary for the proceedings. The law of the State whose assistance is requested shall apply in all cases.

2. The provisions of paragraph 1 of this article shall not affect obligations concerning mutual judicial assistance embodied in any other treaty.

\section{Article 14}

The State Party where the alleged offender is prosecuted shall in accordance with its laws communicate the final outcome of the proceedings to the Secretary-General of the United Nations, who shall transmit the information to the other States concerned.

\section{Article 15}

1. The offences set forth in articles 2, 3 and 4 of the present Convention shall be deemed to be included as extraditable offences in any extradition treaty existing between States Parties. States Parties undertake to include such offences as extraditable offences in every extradition treaty to be concluded between them.

2. If a State Party which makes extradition conditional on the existence of a treaty receives a request for extradition from another State Party with which it has no extradition treaty, it may at its option consider the present Convention as the legal basis for extradition in respect of those offences. Extradition shall be subject to the other conditions provided by the law of the requested State.

3. States Parties which do not make extradition conditional on the existence of a treaty shall recognize those offences as extraditable offences between themselves, subject to the conditions provided by the law of the requested State.

4. The offences shall be treated, for the purpose of extradition between States Parties, as if they had been committed not only in the place in which they occurred but also in the territories of the State required to establish their jurisdiction in accordance with article 9 of the present Convention.

\section{Article 16}

The present Convention shall be applied without prejudice to:
( a ) The rules relating to the international responsibility of States;

(b) The law of armed conflict and international humanitarian law, including the provisions relating to the status of combatant or of prisoner of war.

\section{Article 17}

1. Any dispute between two or more States Parties concerning the interpretation or application of the present Convention which is not settled by negotiation shall, at the request of one of them, be submitted to arbitration. If, within six months from the date of the request for arbitration, the parties are unable to agree on the organization of the arbitration, any one of those parties may refer the dispute to the International Court of Justice by a request in conformity with the Statute of the Court.

2. Each State may, at the time of signature or ratification of the present Convention or accession thereto, declare that it does not consider itself bound by paragraph 1 of this article. The other States Parties shall not be bound by paragraph 1 of this article with respect to any State party which has made such a reservation.

3. Any State Party which has made a reservation in accordance with paragraph 2 of this article may at any time withdraw that reservation by notification to the Secretary-General of the United Nations.

\section{Article 18}

1. The present Convention shall be open for signature by all States until 31 December 1990 at United Nations Headquarters in New York.

2 . The present Convention shall be subject to ratification. The instruments of ratification shall be deposited with the Secretary-General of the United Nations.

3. The present Convention shall remain open for accession by any State. The instruments of accession shall be deposited with the Secretary-General of the United Nations.

\section{Article 19}

1. The present Convention shall enter into force on the thirtieth day following the date of deposit of the twenty-second instrument of ratification or accession with the Secretary-General of the United Nations.

2. For each State ratifying or acceding to the Convention after the deposit of the twenty-second instrument of ratification or accession, the Convention shall enter into force on the thirtieth day after deposit by such State of its instrument of ratification or accession.

\section{Article 20}

1. Any State Party may denounce the present Convention by written notification to the Secretary-General of the United Nations.

2. Denunciation shall take effect one year after the date on which the notification is received by the Secretary-General of the United Nations. 
Article 21

The original of the present Convention, of which the Arabic, Chinese, English, French, Russian and Spanish texts are equally authentic, shall be deposited with the Secretary-General of the United Nations, who shall send certified copies thereof to all States.

In witness whereof the undersigned, being duly authorized thereto by their respective Governments, have signed the present Convention.

\section{International Peace Operations Association (IPOA) Code of Conduct ${ }^{1}$}

\section{Preamble: Purpose}

This Code of Conduct seeks to ensure the ethical standards of International Peace Operations Association member companies operating in conflict and post-conflict environments so that they may contribute their valuable services for the benefit of international peace and human security.

Additionally, Signatories are encouraged to follow all rules of international humanitarian law and human rights law that are applicable as well as all relevant international protocols and conventions, including but not limited to:

- Universal Declaration of Human Rights (1948)

- Geneva Conventions (1949)

- Convention Against Torture (1975)

- Protocols Additional to the Geneva Conventions (1977)

- Chemical Weapons Convention (1993)

- Voluntary Principles on Security and Human Rights (2000) Members of IPOA are pledged to the following principles in all their operations:

\section{Human Rights}

1.1. In all their operations, Signatories will respect the dignity of all human beings and strictly adhere to all relevant international laws and protocols on human rights.

1.2. In all their operations, Signatories will take every practicable measure to minimize loss of life and destruction of property.

\section{Transparency}

2.1. Signatories will operate with integrity, honesty and fairness.

2.2. Signatories engaged in peace or stability operations pledge, to the extent possible and subject to contractual and legal limitations, to be open and forthcoming with the International Committee of the Red Cross and other relevant authorities on the nature of their operations and any conflicts of interest that

1 http://ipoaworld.org/eng/codeofconductv11eng.html might in any way be perceived as influencing their current or potential ventures.

\section{Accountability}

3.1. Signatories understand the unique nature of the conflict/ post-conflict environment in which many of their operations take place, and they fully recognize the importance of clear and operative lines of accountability to ensuring effective peace operations and to the long-term viability of the industry.

3.2. Signatories support effective legal accountability to relevant authorities for their actions and the actions of company employees. While minor infractions should be proactively addressed by companies themselves, Signatories pledge, to the extent possible and subject to contractual and legal limitations, to fully cooperate with official investigations into allegations of contractual violations and violations of international humanitarian law and human rights law.

3.3. Signatories further pledge that they will take firm and definitive action if employees of their organization engage in unlawful activities.

\section{Clients}

4.1. Signatories pledge to work only for legitimate, recognized governments, international organizations, non-governmental organizations and lawful private companies.

4.2. Signatories refuse to engage any unlawful clients or clients who are actively thwarting international efforts towards peace.

4.3. Signatories pledge to maintain the confidentiality of information obtained through services provided, except when doing so would jeopardize the principles contained herein.

\section{Safety}

5.1. Recognizing the often high levels of risk inherent to business operations in conflict/post-conflict environments, Signatories will always strive to operate in a safe, responsible, consci- 